\title{
The role of Coenzyme Ubquinone CoQ10 in modulating the changes induced by the antidepressant Venlafaxine in albino rats fetuses
}

\author{
Abu Gabal, $\mathrm{H}^{*}$ and Al Shabanat, $\mathrm{F}^{* *}$ \\ * College of Science and Humanities, Soliman Bin Abdul Aziz University. \\ **College of Science, Princess Nora Bent Abdul Rahman University.
}

\begin{abstract}
Aim of the work:The present study was done to investigate the role played by CoQ10 in the control of the morphological and histological changes induced in the fetuses of rats injected by the antidepressant Venlafaxine.

Material and methods: 70 pregnant Wister wister rats were injected Intraperitonealy during the organogenesis period with the antidepressant Venlafaxine $(0.25 \mathrm{mg} / 100 \mathrm{~g}$.body weight $)$ on day 7 of gestation.Mean number of alive embryos, weight and length of them were recorded with the noticeable malformations beside maternal weights. The protective role of CoQ10 $(0.6 \mathrm{mg}$. $/ 100 \mathrm{~g}$. body weight) was also detected.

Results: Venlafaxine injection induced a very highly significant decrease in the mean maternal and fetal body weights, the two horns of the uteri appeared unequal as well as the fetuses were unequally distributed between them, beside the appearance of a lot of resorbed bodies into them, also fat sacs were clear, a case of ectopic pregnancy was obvious, as well as very highly significant decrease in the mean number of alive fetuses was noticed, fetal growth retardation beside lots of rat fetal malformations were observed such as subcutaneous blood bleeding, cleft lips and anomalies of the fore and hind limbs as well as kyphosis of the body.

Intraperitonealy injection of Venlafaxine by the fractionated dose $(0.75 \mathrm{mg} . / 100 \mathrm{~g}$ body weight) on days 7,10 and 13 of gestation $0.25 \mathrm{mg}$. $/ 100 \mathrm{~g}$ each resulted in the death of all the pregnant rats. CoQ10 (0.6 mg. $/ 100 \mathrm{~g}$. body weight) orally injected to the pregnant rats before Venlafaxine treatment at the two doses $(0.25$ and $0.75 \mathrm{mg} . / 100 \mathrm{~g}$.body weight $)$ improved the above morphometric and morphological as well as the skeletal system changes.

Conclusion : CoQ10 (0.6 mg. /100g. body weight $)$ orally injected to the pregnant rats treated with Venlafaxine showed protective effect against the dangerous changes induced by this antidepressant.
\end{abstract}

\section{Introduction}

An antidepressant is a psychiatric medication used to alleviate mood disorders, such as major depression, dysthymia and anxiety disorders (Smith et al., 2010). Drugs including the monoamine oxidase inhibitors (MAOIs), tricyclic antidepressants (TCAs), tetracyclic antidepressants (TeCAs), selective serotonin reuptake inhibitors (SSRIs), and serotonin-norepinephrine reuptake inhibitors (SNRIs) are most commonly associated with the term (Rubino et al.,2007). These medications are among those most commonly prescribed by psychiatrists and other physicians, their effectiveness and adverse effects are the subjects of many studies and competing claims (Tiihonen et al., 2006).

The management of depression in pregnancy is complex, as it is based on balancing the risks with the benefits of treatment versus no treatment for both the mother and the fetus. Studies have shown that exposure to mental illness in pregnancy has deleterious short-term and long-term effects for the exposed mother and fetus (Dimidjian et al.,2009;Raudzus and Misri, 2009).On the other hand untreated depression during pregnancy has been 
associated with miscarriage, perinatal complications and increased admissions to neonatal intensive care. Depression that is

not treated during pregnancy can be associated with premature birth and low birth weights (Yonkers, 2009).

Venlafaxine is an antidepressant of the serotonin-norepinephrine reuptake inhibitor (SNRI) class .It is prescribed for the treatment of clinical depression and anxiety disorders (Adan-Manes et al., 2006). However, treatment of pregnant women with Venlafaxine induced developmental toxicities including spontaneous abortions, prematurity, fetal growth retardation, neonatal serotonin syndrome, neonatal behavioral syndrome such as withdrawal and respiratory distress ( Simon et al,2002;Hendrick et al,2003 ).On the other hand Venlafaxine treatment was consistently associated with higher risk of mothers suicidal ideation compared with other SSRIs (Rubino et al, 2007; Wogelius, et a.l, 2007 ;Salvatore, 2008). Källén and Olausson_(2007) found that maternal use of selective serotonin re-uptake inhibitors (SSRIs) has been associated with an increased risk of infant malformations such as cystic kidneys, cardiovascular defects as ventricular and atrial septum defects as well as craniostenosis or omphalocele.Neonatal behavioral signs included central nervous, respiratory, and digestive systems, as well as hypoglycemia and vomiting, tachycardia, and jaundice in the exposed group were reported by Wan (2007).

CoQ10 is a naturally occurring compound found in every cell in animal organisms and in humans. It plays a key role in mitochondrial bioenergetics, it is also extensively investigated to play antioxidant role in preventing the generation of free radicals as well as oxidative modifications of proteins, lipids, and DNA ( Siemieniuk and Skrzydlewska ,2005; Littarru and Tiano ,2007 ; López et al.,2010) .These compounds could potentially play a role in the treatment of mitochondrial disorders, Parkinson's disease, Huntington's disease, amyotrophic lateral sclerosis, Friedreich's ataxia, and other conditions of neurodegenerative and neuromuscular disorders (Mancuso et al.,2010). Quinzii et al, (2010) found that CoQ 10 deficiency caused variable defects of ATP synthesis and oxidative stress.

There is a relationship between CoQ 10 and fetal development, Haruna et al. (2010) concluded that the level of maternal CoQ10 is positively associated with fetal growth, as well as balanced rapid metabolic changes during pregnancy. Bentov et al, (2010) cited that the use of mitochondrial nutrients improve the outcome of reproductive dysfunction.

\section{Material and Methods:}

70 Wister wister mature virgin female rats (160-180g.body weight) were used in the present work and 35 males for mating. The rats were obtained from King Faisal specialist hospital research centre .The animals were kept under adequate dietary, ventilation and humidity conditions. Pregnancy was ascertained by daily examinations of vaginal smears (Taylor, 1986)

The experimental animals were divided into 3 main groups:

I- The control group(normal group):

In this group the pregnant rats were injected Intraperitonealy by distilled water $0.25 \mathrm{ml} / 100 \mathrm{~g}$. (The solvent of Venlafaxine) on days 7, 10 and 13 of gestation.

II-The experimental control groups: a- In this group pregnant rats were orally administered with olive oil (the solvent of Co Q10) on days 7,10 and 13 of gestation.

b- In this group animals were orally administered with CoQ10 at a dose $0.6 \mathrm{mg} . / 100 \mathrm{~g}$.body weight) on days 7,10 and 13 of gestation.

III-The experimental groups: a- In this group pregnant rats were injected Intraperitonealy by Venlafaxine at a dose

$0.25 \mathrm{mg} . / 100 \mathrm{~g}$ body weight on day 7 of gestation. 
Hanaa Abu Gabal and Fawzya Al Shabanat

b- In this group pregnant rats were injected Intraperitonealy by Venlafaxine at a dose $0.75 \mathrm{mg} / 100 \mathrm{~g}$ body weight fractionated on days 7,10 and 13 of gestation $(0.25 \mathrm{mg}$ $/ 100 \mathrm{~g}$ each).

c- In this group pregnant rats were orally administered with CoQ10 at a dose $0.6 \mathrm{mg} . / 100 \mathrm{~g}$ body weight (on days 7, 10 and 13 of gestation) then injected Intraperitonealy by Venlafaxine at a dose $0.25 \mathrm{mg} . / 100 \mathrm{~g}$ body weight (day 7 of gestation).

d- In this group pregnant rats were orally administered with CoQ10 at a dose $0.6 \mathrm{mg}$. $/ 100 \mathrm{~g}$ body weight (on days 7, 10 and 13 of gestation) then injected Intraperitonealy by Venlafaxine at a dose $0.75 \mathrm{mg} . / 100 \mathrm{~g}$.body weight (fractionated on days 7, 10 and 13 of gestation).

The number of the pregnant rats in all the previous treated groups is ten rats.

\section{I- Maternal Investigations:}

1- The female rats were weighed pregestation with Sartorius 1104.

2-Pregnant rats were weighed on days 7, 10 and 13 of gestation to evaluate the increase in the body weight due to pregnancy.

3- Observing of blood from the vaginal opening, of the pregnant female was taken as an indication of abortion.

4- The mortality rate in the different groups was illustrated.

\section{II- Embryological Investigations:}

The embryos were examined carefully for the following studies:

1-The mean number of alive, dead and malformed embryos for each group.

2- The mean body weight of live embryos using Metller balance.

3- The mean body length of live embryos was measured in $\mathrm{cm}$. using a compass filament.

4-The malformed embryos were examined carefully and photographed.

5- Alizarin red $\mathrm{S}$ stain (Bancroft and Gamble, 2002) was used for the demonstration of the possible skeletal abnormalities.

\section{Results}

Results of the pregnant rats indicated that intraperitonealy injection of Venlafaxine at a dose $0.25 \mathrm{mg} . / 100 \mathrm{~g}$.body weight on day 7 of gestation induced a very highly significant decrease $(p<0.001)$ in the mean maternal body weights, the uterine weights, the two horns of the uteri appeared unequal as well as the fetuses were unequally distributed between them with appearance of lots of resorbed bodies into them, also fat sacs were clear, a case of ectopic pregnancy was obvious. However Venlafaxine intraperitonealy fractionated injection (0.75mg./100g.body weight) on days 7, 10 and 13 of gestation led to the death of all the pregnant rats. Orally administration with CoQ10 (0.6mg./100g.body weight) showed improvement of all the above mentioned parameters induced by the antidepressant Venlafaxine (Figs.1, 2 and3 a, $\mathrm{b}, \mathrm{c}, \mathrm{d} \& \mathrm{e})$

Results of the fetuses showed that intraperitonealy injection of pregnant rats with Venlafaxine (0.25mg./100g.body weight) on day 7 of pregnancy induced a very highly significant decrease $(p<0.001)$ in the number of live fetuses, fetal body weights as well as body lengths. CoQ10 orally administration to pregnant rats before Venlafaxine injection at the two doses $(0.25$ and $0.75 \mathrm{mg} . / 100$ g.body weight) resulted in very highly significant $(\mathrm{p}<0.001)$ improvement in the morphometric changes; however neither maternal deaths nor fetal deaths occurred (Figs. 4, 5\&6).

Lots of malformations were observed after maternal Venlafaxine injection $(0.25 \mathrm{mg}$. $1100 \mathrm{~g}$. body weight )such as variation of the body sizes of the fetuses even of the same mother, thin and fragile fetal skin was observed, as well as congestion of blood vessels in the head and ear regions, 

The role of.....

subcutaneous hemorrhage was observed. Malformed rostrum (cleft lips), anomalies of the fore and hind limbs as well as kyphosis of the body were noticed (Figs7-9).

The axial and peripheral fetal skeletal systems were affected as follows; increased of the number of non ossified bones in comparison to the control group (Figs.12-14\& Tables1-4).

CoQ10 injection before Venlafaxine injection (at the two doses) improved the external morphology as well as the changes in the skeletal system (Figs.15\&16\&Tables 1-4)

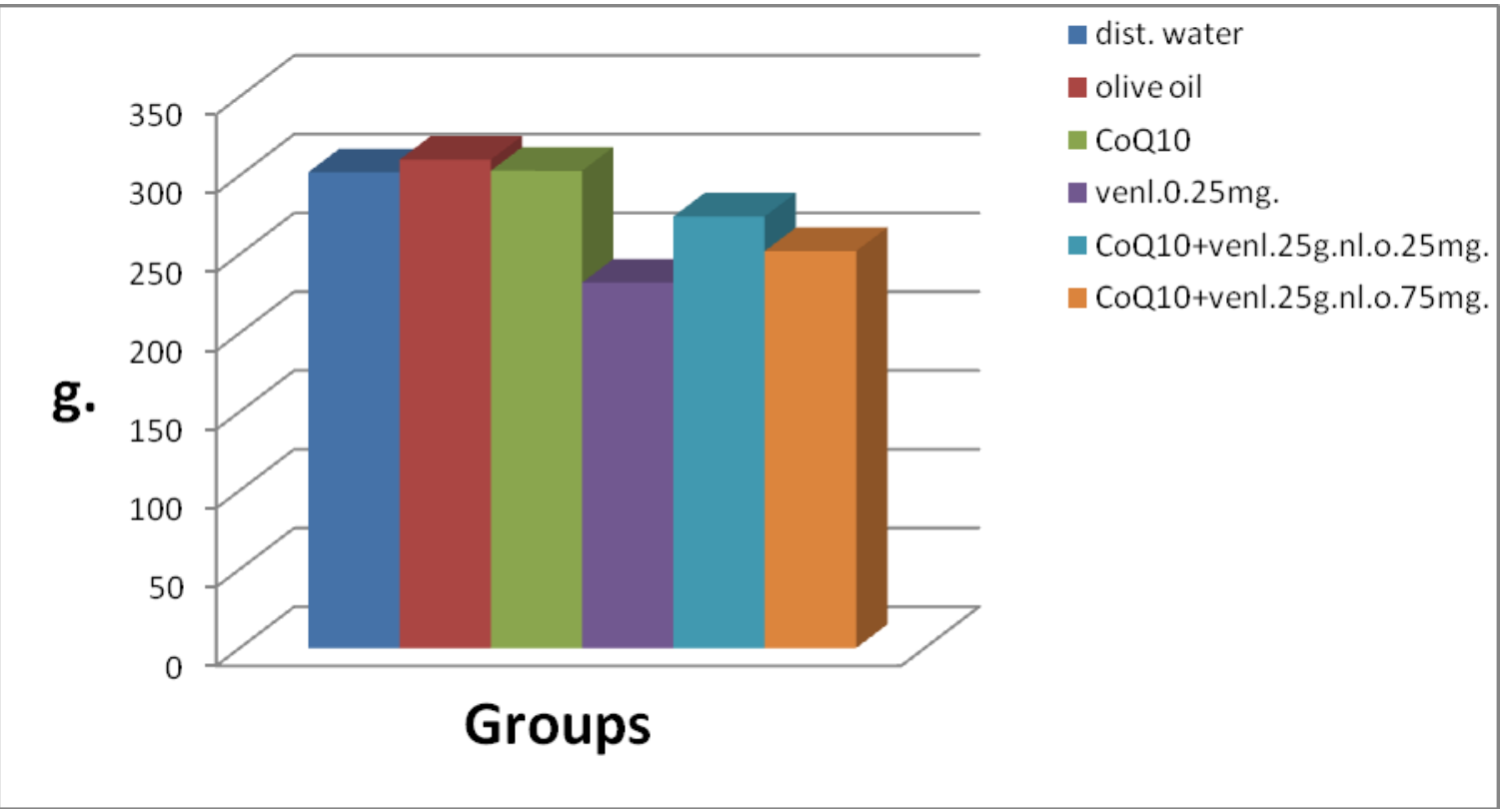

Fig.1: Mean body weights (g.) of pregnant rats in the different groups on day 19 of gestation.

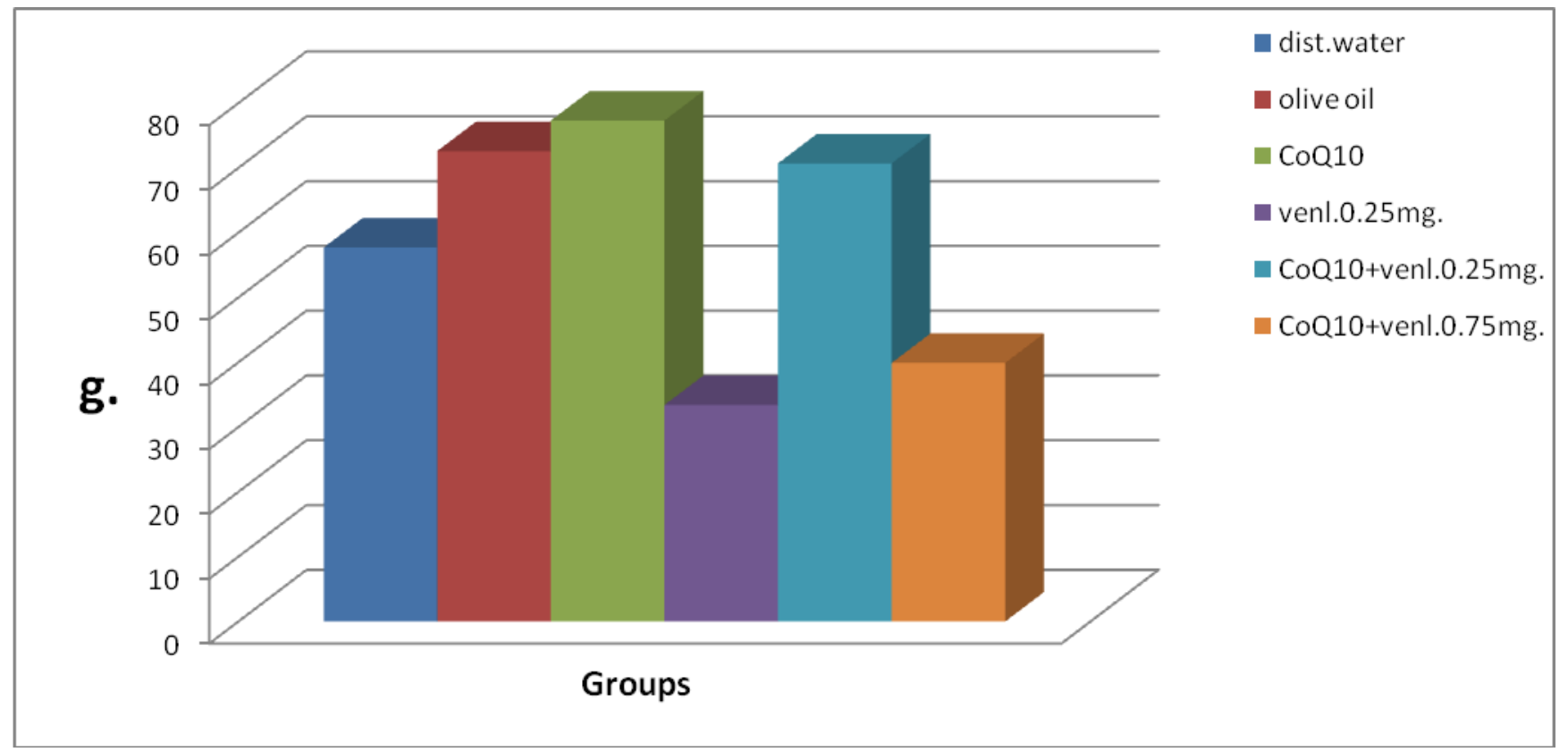

Fig. 2: Mean uterine weights of pregnant rats in the different groups on day 19 of gestation. 
Fig.3 (a): A uterus of control rat group on day 19 of gestation showing that the two horns are equal.
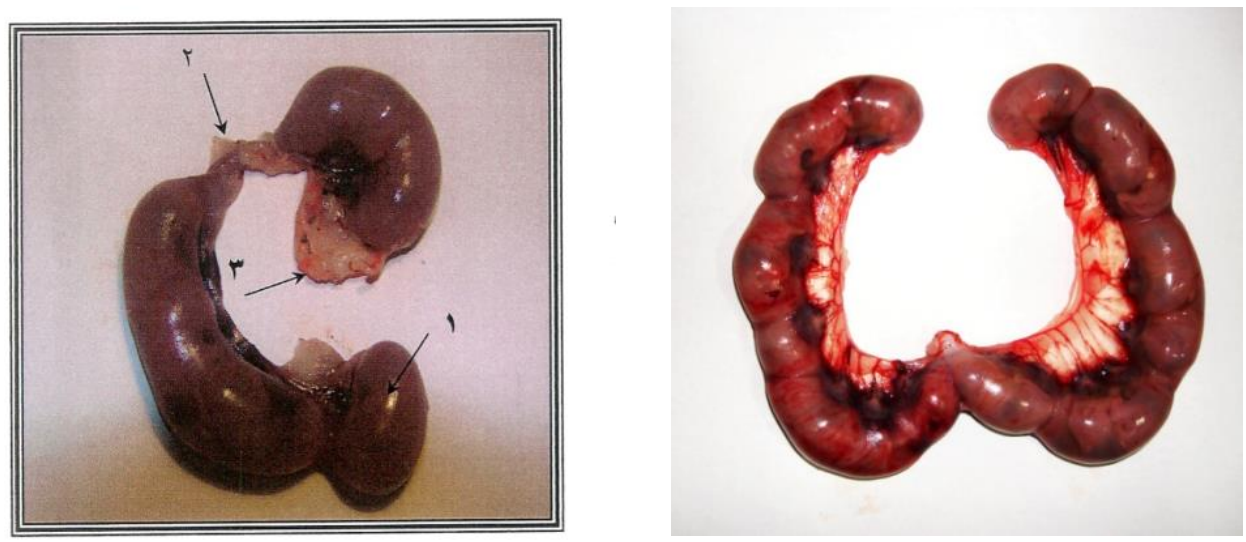

Fig.3 (b): A uterus of Venlafaxine treated group (0.25mg. $/ 100$ g.b.w.) on day 19 of gestation the two horns are unequal(1), the fetuses were unequally distributed between them(2), as well as fat sacs are obvious(3).

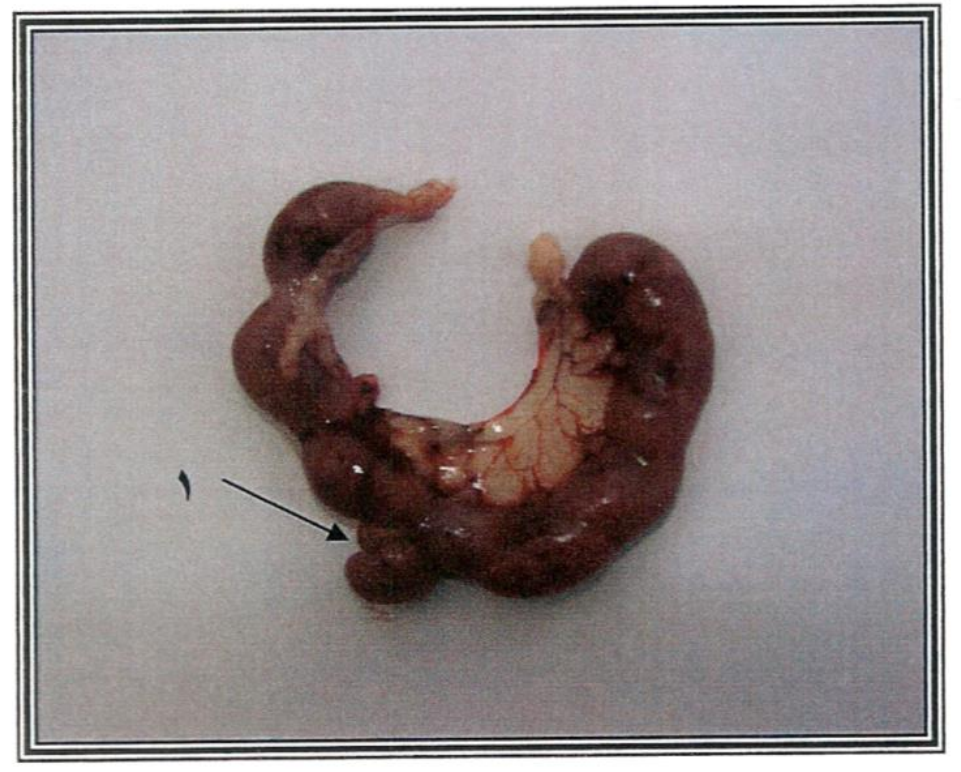

Fig.3 (c): The uteri of Venlafaxine group (0.25mg. /100g.b.w.) ectopic pregnancy (1), resorbed bodies are obvious (2). 
The role of.....

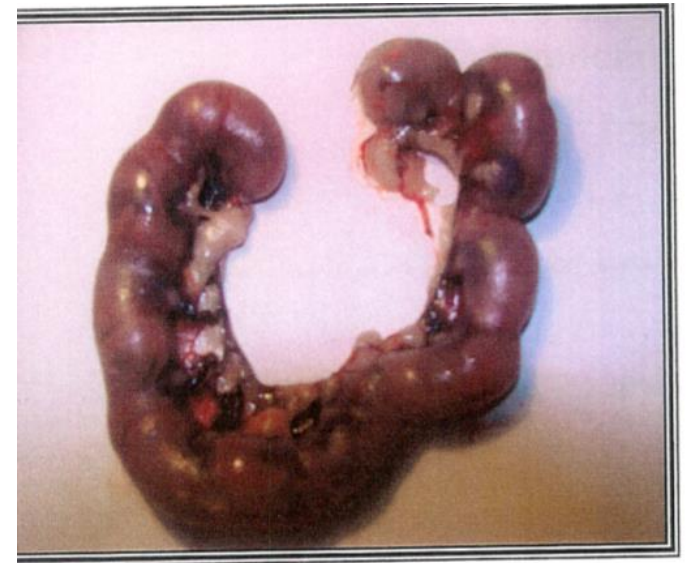

Fig.3 (d): The uteri of the Venlafaxine group (0.025mg. /100g.b.w.) after CoQ10 injection (0.6mg. $/ 100$ g.b. w.) improvements of the uterine morphology are obvious.

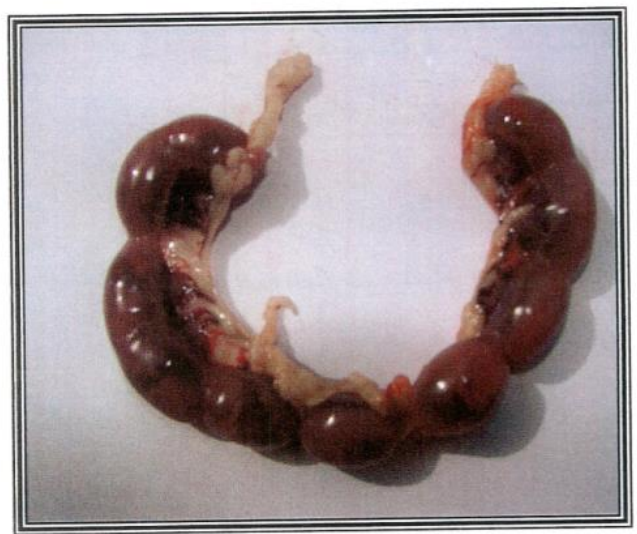

Fig.3 (e): The uteri of the Venlafaxine group (0.75mg. /100g.b.w.) After CoQ10 injection (0.6mg. $/ 100$ g. b.w.) Improvements of the uterine morphology are obvious. 



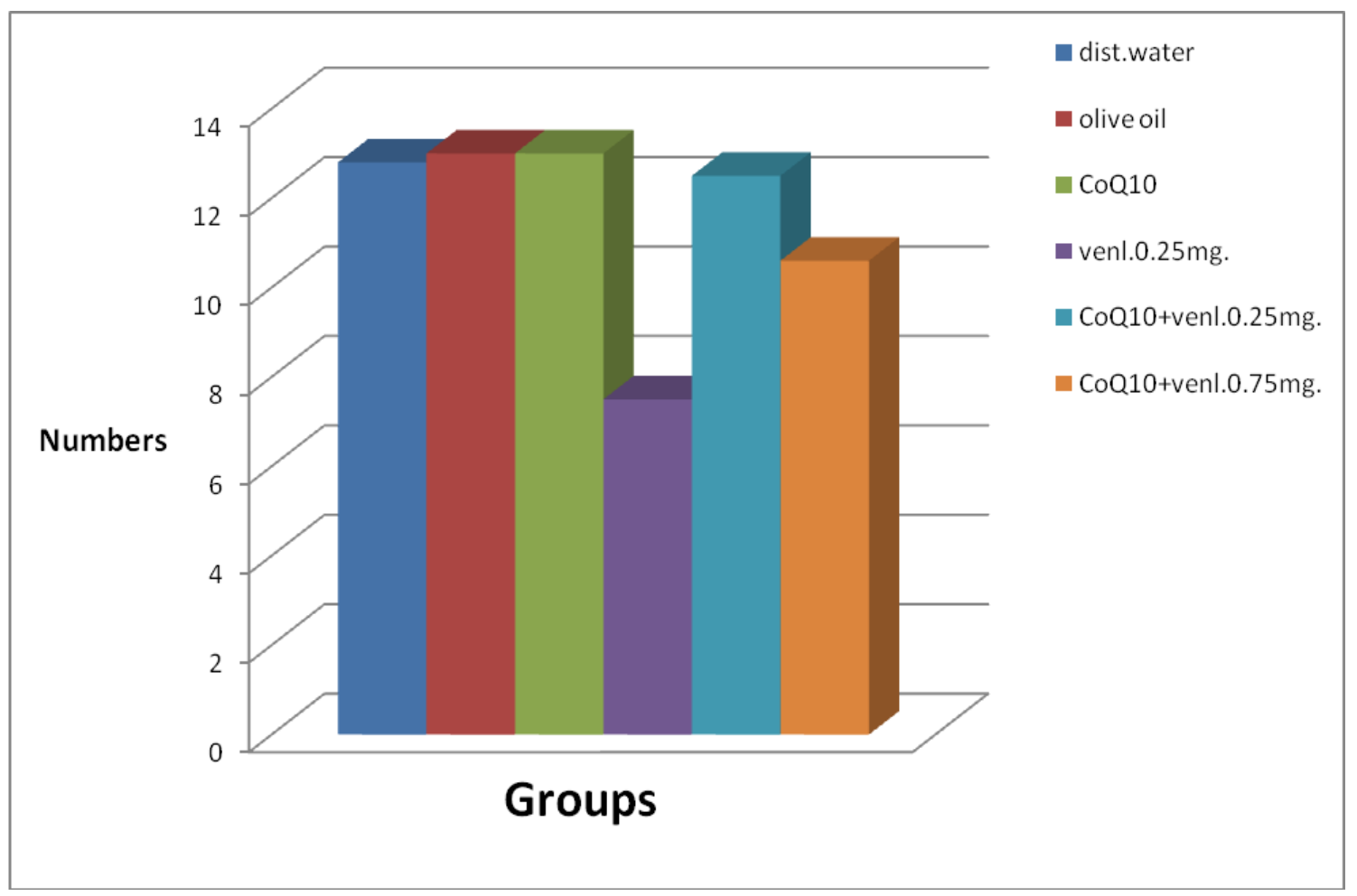

Fig 4: Mean number of live fetuses of the different female rat groups on day 19 of gestation.

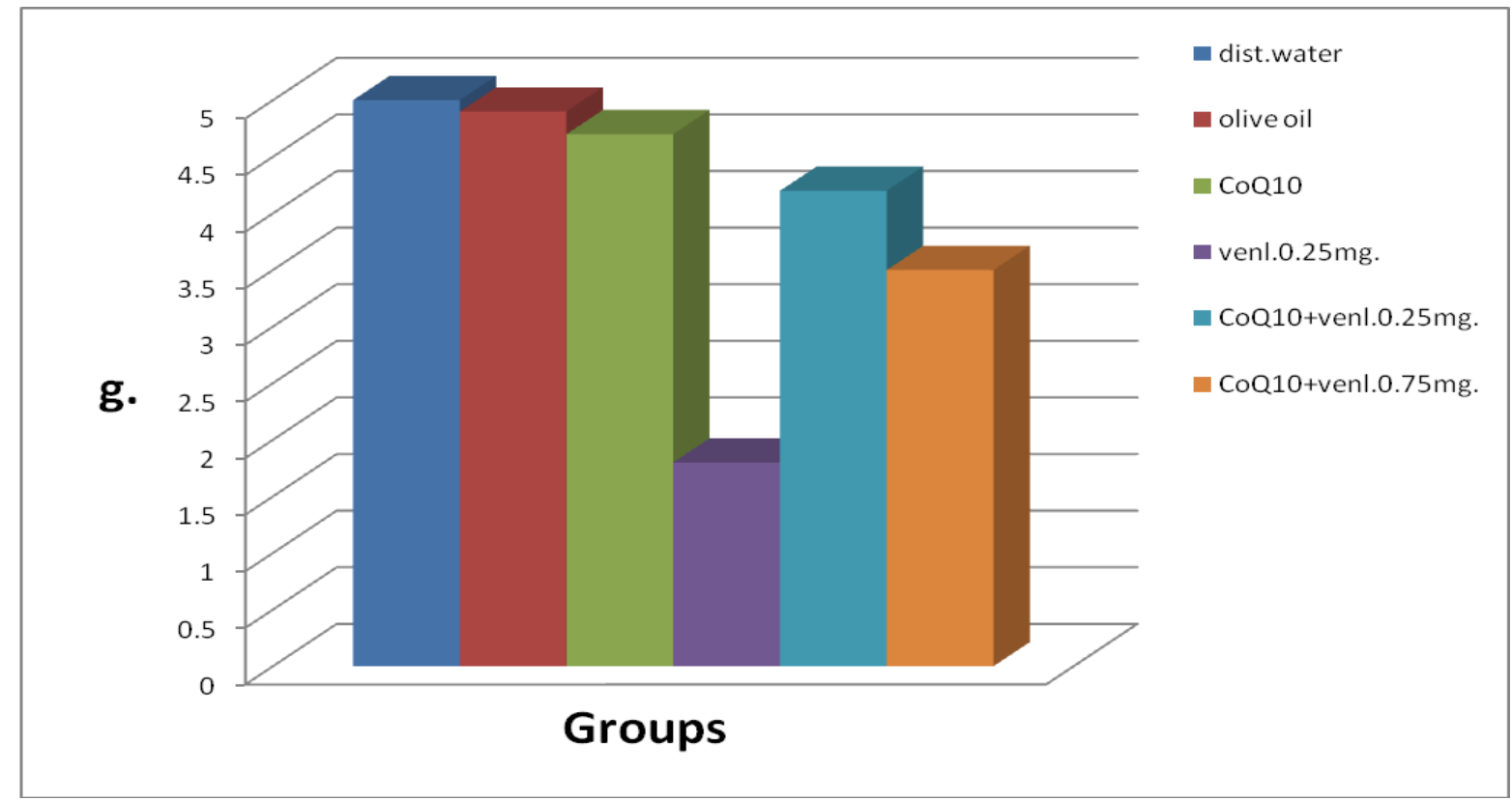

Fig.5: Mean body weights (gm.) of live fetuses of the different groups on day 19 of gestation. 
The role of.....

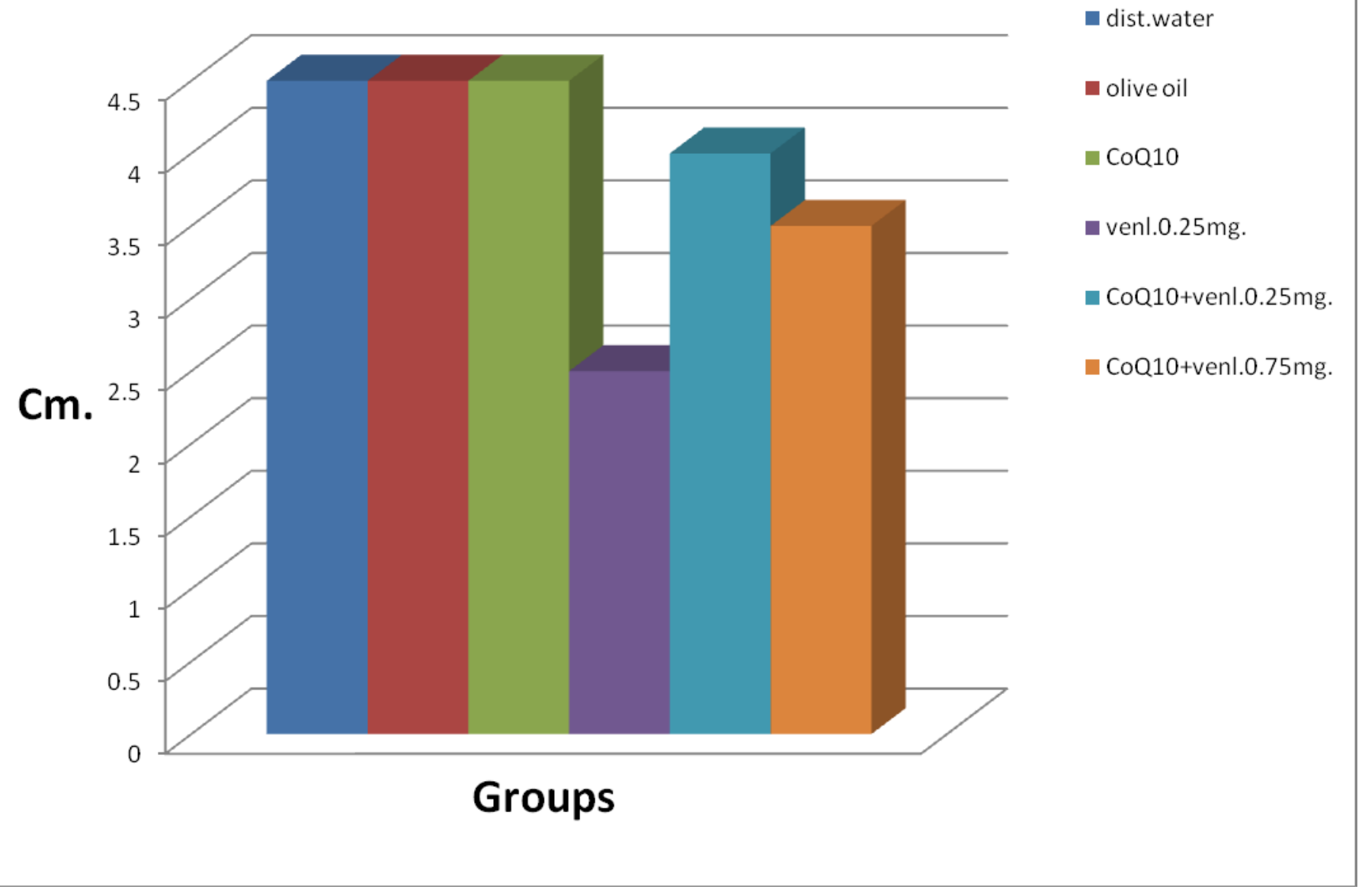

Fig.6: Mean body lengths (cm.) of live fetuses of the different rat groups on day 19 of gestation.

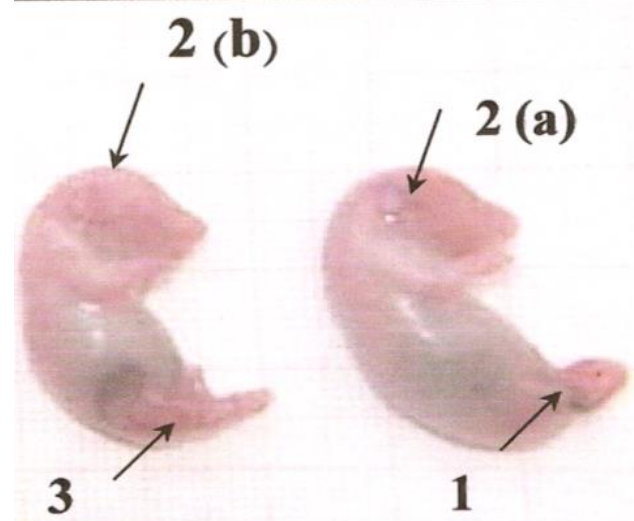

Fig.7: Fetuses maternally injected with Venlafaxine (0.25mg./100g.b.w.)showing subcutaneous hemorrhage (1), subcutaneous blood vessels congestion (2a\&b)and Phocomelia of the limbs (3). 


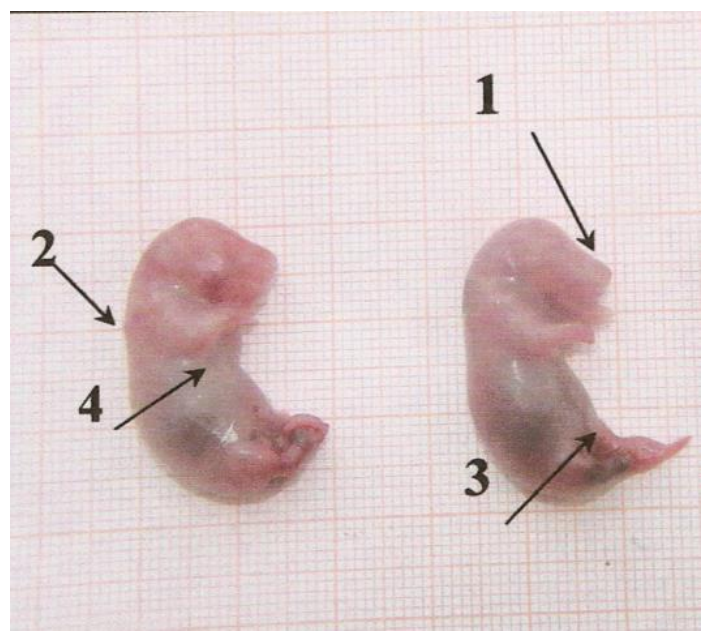

Fig.8: fetuses maternally injected with Venlafaxine (0.25g./100g.b.w.)showing cleft lips (1), kyphosis (2), subcutaneous hemorrhage (3) and hypertrophy of the abdomen region.

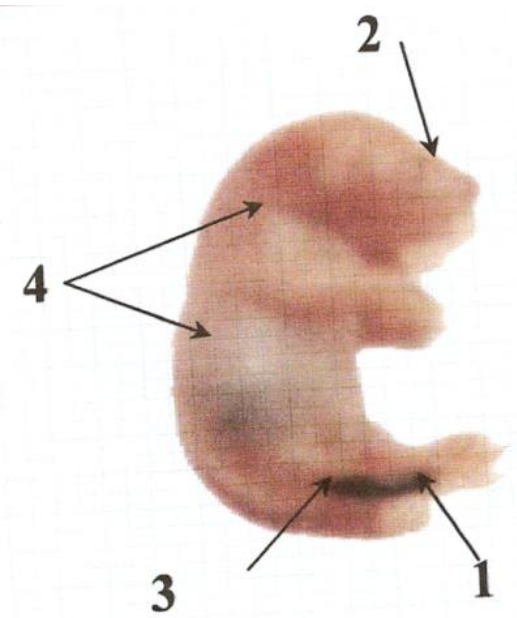

Fig.9: fetuses maternally injected with Venlafaxine (0.25mg./100g.b.w.)showing Phocomelia of the limbs (1), cleft lips (2), subcutaneous hemorrhage (3) and fragile skin (4).

Fig.10: Fetus of rat $19^{\text {th }}$ day of gestation maternally administrated with CoQ10 then Venlafaxine injected $(0.25 \mathrm{mg}$. $/ 100 \mathrm{~g}$.b.w.) showing improvements of the morphological features. 

The role of.....
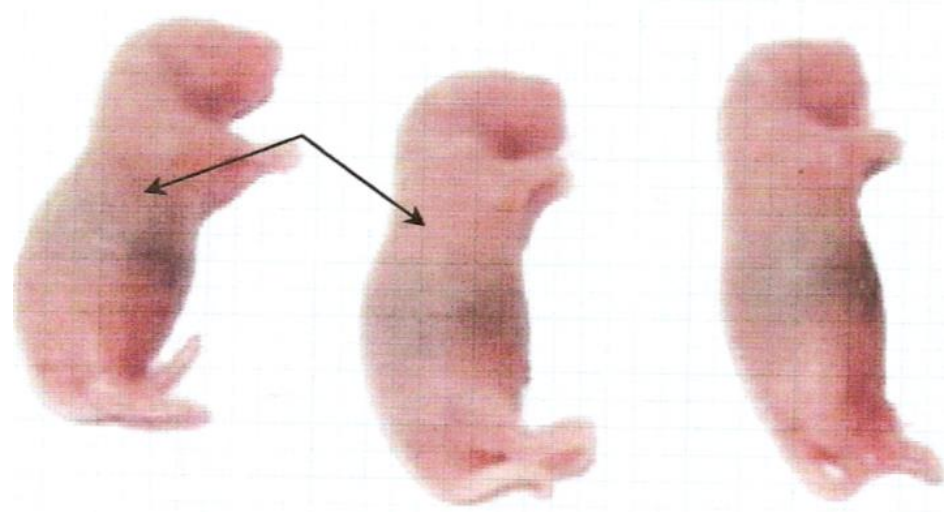

Fig.11: Fetus of rat $19^{\text {th }}$ day of gestation maternally administrated with CoQ10 then Venlafaxine injected $(0.75 \mathrm{mg}$. $/ 100 \mathrm{~g}$.b.w.) show some improvements, however still some malformations appeared.

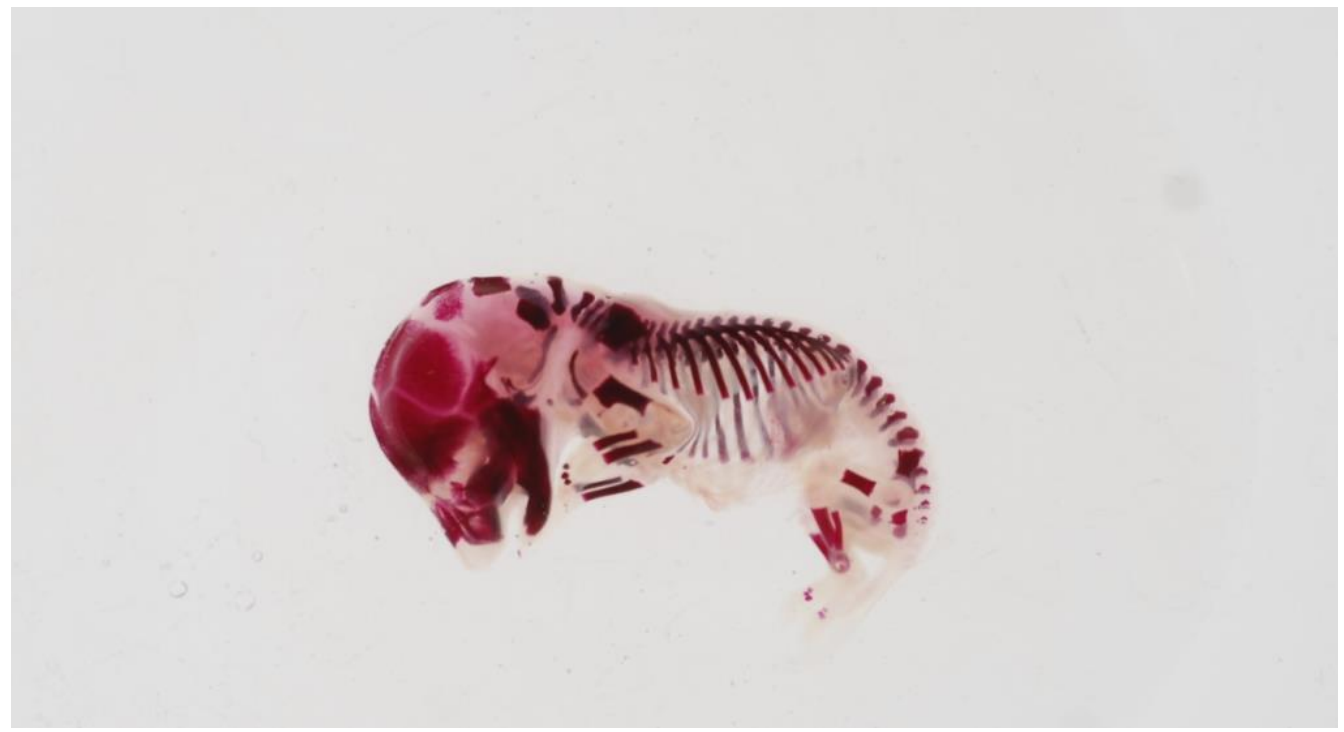

Fig. 12: Skeletal system of rat fetus $19^{\text {th }}$ day of gestation, after distilled water treatment (Alizarin red S) X: 1.3. 


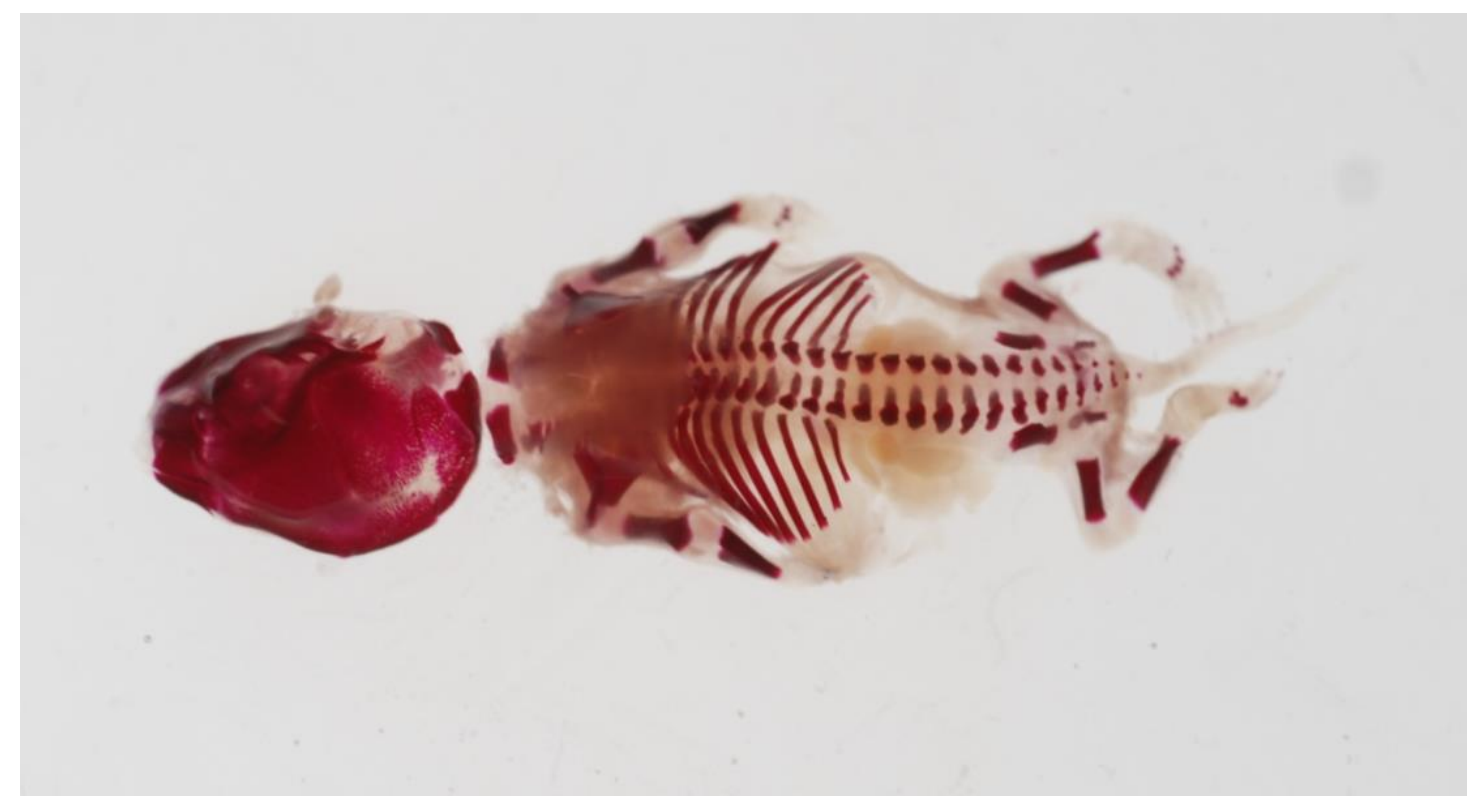

Fig.13: Skeletal system of rat fetus $19^{\text {th }}$ day of gestation maternally administrated with Co Q10 (Alizarin red S) X: 2.4.

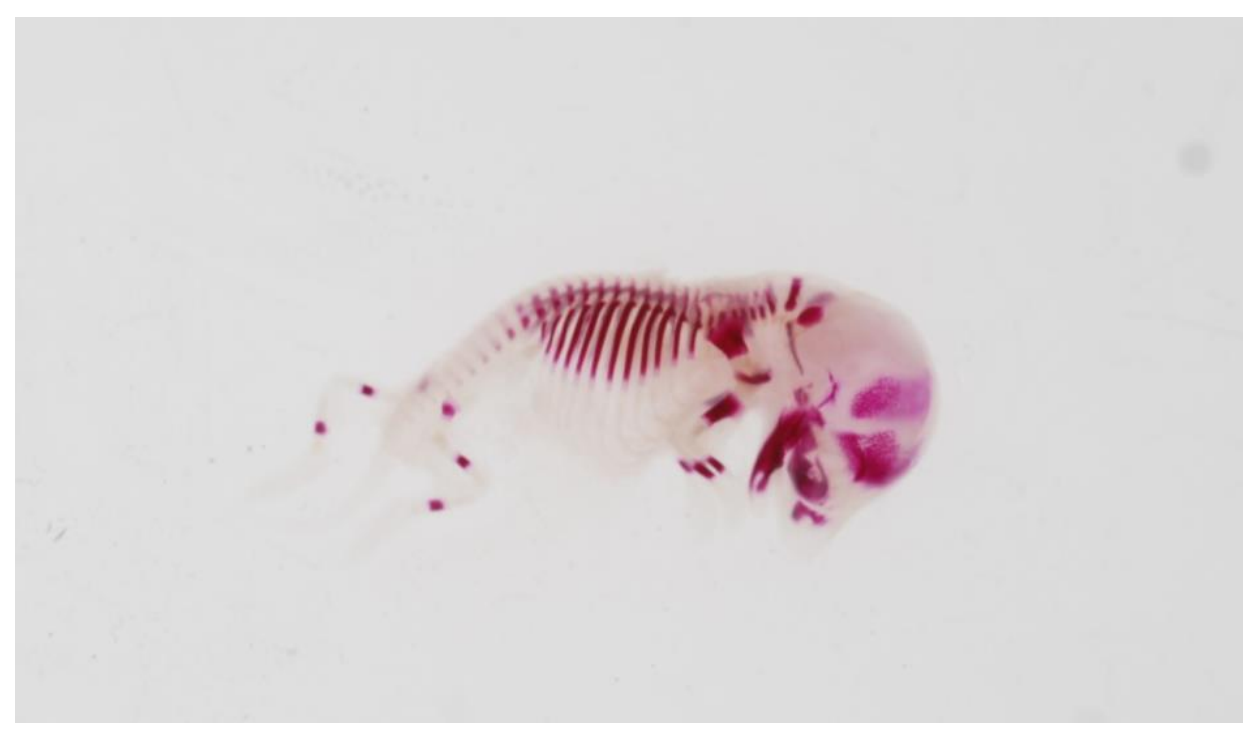

Fig.14: Rat fetal skeletal system $19^{\text {th }}$ day of gestation, maternally injected with Venlafaxine (0.25mg./100g.b.w.) (Alizarin red S)X: 2.8 . 


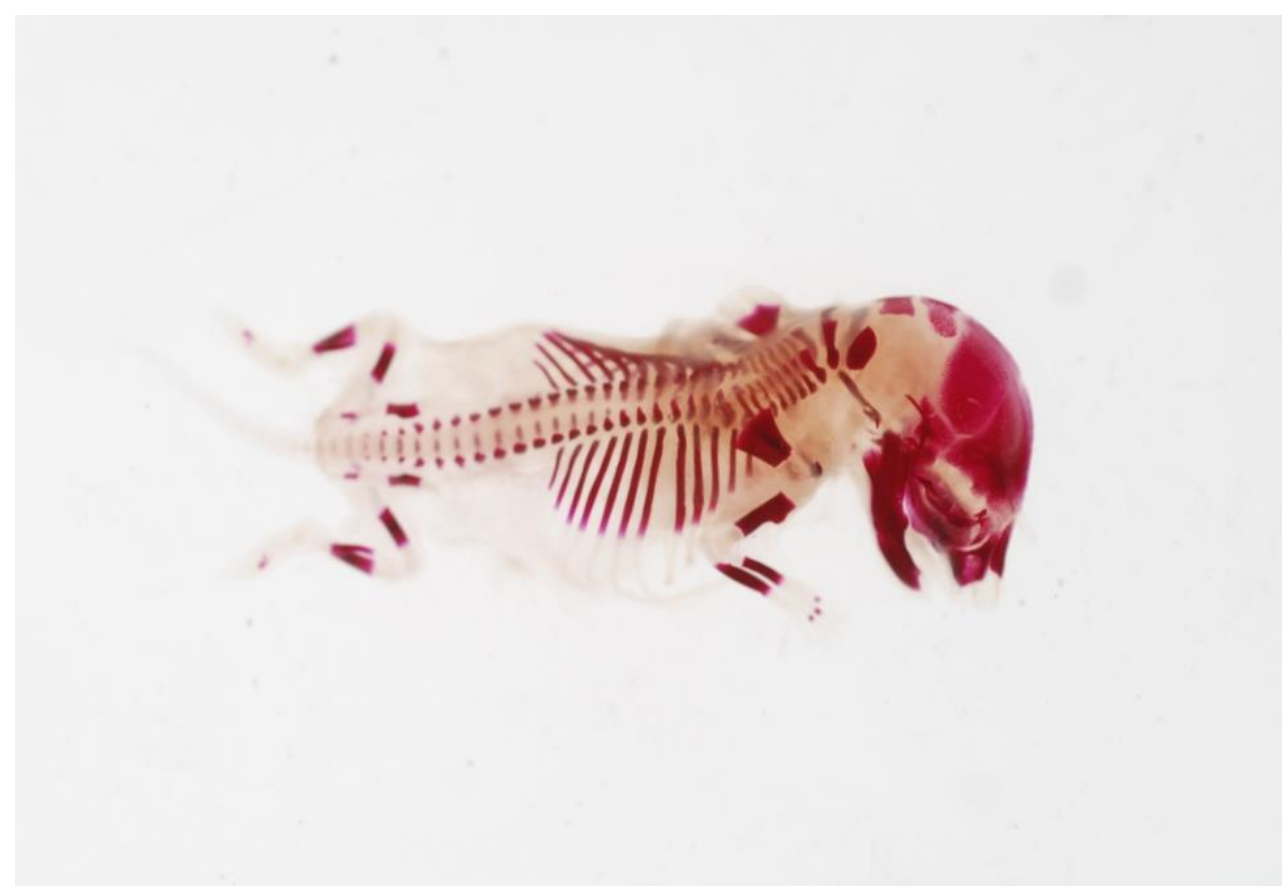

Fig.15: Rat fetal skeletal system $19^{\text {th }}$ day of gestation, maternally administrated with CoQ10 then injected with Venlafaxine (0.25mg./100g.b.w.) (Alizarin red S)X: 1.75.

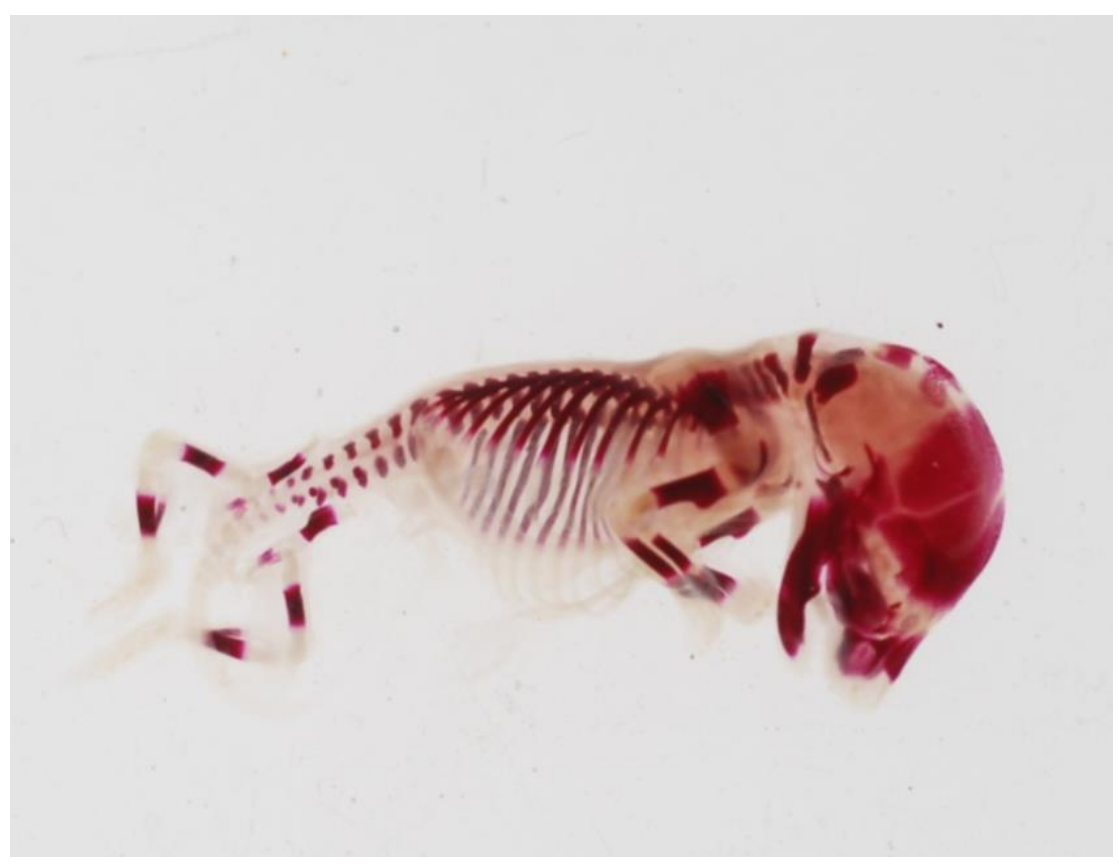

$10 \mathrm{~mm}$

Fig.16: Rat fetal skeletal system $19^{\text {th }}$ day of gestation, after maternally CoQ10 administration then Venlafaxine injection (0.75mg./100g.b.w.) (Alizarin red S)X: 2.28 . 



\begin{tabular}{|c|c|c|c|c|c|c|}
\hline Groups & $\begin{array}{l}\text { Control } \\
\text { group } \\
\text { (distilled } \\
\text { water) }\end{array}$ & $\begin{array}{l}\text { Experimental } \\
\text { Control } \\
\text { group (olive } \\
\text { oil) }\end{array}$ & $\begin{array}{l}\text { CoQ10 } \\
\text { group }\end{array}$ & $\begin{array}{l}\text { Venlafaxine } \\
\text { group } \\
\text { (0.25mg/g.b.w.) }\end{array}$ & $\begin{array}{l}\text { CoQ10+Venlafaxine } \\
\text { (o.25mg./g.b.w.) }\end{array}$ & $\begin{array}{l}\text { CoQ10+Venlafas } \\
\text { (o.75mg./g.b.w.) }\end{array}$ \\
\hline Premaxilla & + & + & + & + & + & + \\
\hline Maxilla & + & + & + & + & + & + \\
\hline Nasal & + & + & + & - & + & + \\
\hline Frontal & + & + & + & + & + & + \\
\hline Parietal & + & + & + & - & - & - \\
\hline Interparietal & + & + & + & - & - & - \\
\hline Squamosal & + & + & + & + & + & + \\
\hline Jugal & + & + & + & - & + & + \\
\hline Exooccipital & + & + & + & + & + & + \\
\hline Supraoccipital & + & + & + & - & + & + \\
\hline Basioccipital & + & + & + & - & + & + \\
\hline Tympanicum & + & + & + & - & - & - \\
\hline
\end{tabular}

Table1: Skull Bones of fetuses of different groups $19^{\text {th }}$ day of gestation.

(+) ossified (-) non-ossified

\begin{tabular}{|c|c|c|c|c|c|c|}
\hline Groups & $\begin{array}{l}\text { Control } \\
\text { group } \\
\text { (distilled } \\
\text { water) } \\
\end{array}$ & $\begin{array}{l}\text { Experimental } \\
\text { Control } \\
\text { group (olive } \\
\text { oil) } \\
\end{array}$ & $\begin{array}{l}\text { CoQ10 } \\
\text { group }\end{array}$ & $\begin{array}{l}\text { Venlafaxine } \\
\text { group } \\
(0.25 \mathrm{mg} / \text { g.b.w. })\end{array}$ & $\begin{array}{l}\text { CoQ10+Venlafaxine } \\
\text { (o.25mg./g.b.w.) }\end{array}$ & $\begin{array}{l}\text { CoQ10+Venlafaxi } \\
\text { (o.75mg./g.b.w.) }\end{array}$ \\
\hline Cervical & 7 & 7 & 7 & 7 & 7 & 7 \\
\hline Thoracic & 12 & 12 & 12 & 12 & 12 & 12 \\
\hline Lumbar & 7 & 7 & 7 & 7 & 7 & 7 \\
\hline Sacral & 4 & 4 & 4 & - & 3 & 3 \\
\hline Caudal & 14 & 14 & 14 & - & 14 & - \\
\hline
\end{tabular}

Table2: Fetal vertebrae of different groups $19^{\text {th }}$ day of gestation.

(+) ossified (-) non-ossified 


\begin{tabular}{|c|c|c|c|c|c|c|}
\hline Groups & $\begin{array}{l}\text { Control } \\
\text { group } \\
\text { (distilled } \\
\text { water) }\end{array}$ & $\begin{array}{l}\text { Experimental } \\
\text { Control } \\
\text { group (olive } \\
\text { oil) }\end{array}$ & $\begin{array}{l}\text { CoQ10 } \\
\text { group }\end{array}$ & $\begin{array}{l}\text { Venlafaxine } \\
\text { group } \\
(0.25 \mathrm{mg} / \text { g.b.w. })\end{array}$ & $\begin{array}{l}\text { CoQ10+Venlafaxine } \\
\text { (o.25mg./g.b.w.) }\end{array}$ & $\begin{array}{l}\text { CoQ10+Venlafaxil } \\
\text { (o.75mg./g.b.w.) }\end{array}$ \\
\hline Scapula & + & + & + & + & + & + \\
\hline $\begin{array}{l}\text { Supra- } \\
\text { Scapula }\end{array}$ & + & + & + & + & + & + \\
\hline Clavicle & + & + & + & + & + & + \\
\hline Sternebrae & $(6)+$ & $(6)+$ & $(6)+$ & $(4)+$ & $(6)+$ & $(6)+$ \\
\hline Ribs & 13 & 13 & 13 & 13 & 13 & 13 \\
\hline Humerus & + & + & + & + & + & + \\
\hline Radius & + & + & + & + & + & + \\
\hline Ulna & + & + & + & - & + & + \\
\hline Meta-carpals & $(5)+$ & $(5)+$ & $(5)+$ & - & $(5)+$ & - \\
\hline $\begin{array}{l}\text { Phalanges of } \\
\text { fingers }\end{array}$ & + & + & + & - & - & - \\
\hline
\end{tabular}

Table 3: Bones of the pectoral girdle and fore-limb of fetuses of the different groups $19^{\text {th }}$ day of gestation.

(+) ossified (-) non-ossified

\begin{tabular}{|c|c|c|c|c|c|c|}
\hline Groups & $\begin{array}{l}\text { Control } \\
\text { group } \\
\text { (distilled } \\
\text { water) }\end{array}$ & $\begin{array}{l}\text { Experimental } \\
\text { Control } \\
\text { group (olive } \\
\text { oil) }\end{array}$ & $\begin{array}{l}\text { CoQ10 } \\
\text { group }\end{array}$ & $\begin{array}{l}\text { Venlafaxine } \\
\text { group } \\
(0.25 \mathrm{mg} / \mathrm{g} . \mathbf{b . w} .)\end{array}$ & $\begin{array}{l}\text { CoQ10+Venlafaxine } \\
\text { (o.25mg./g.b.w.) }\end{array}$ & $\begin{array}{l}\text { CoQ10+Venlafaxiı } \\
\text { (o.75mg./g.b.w.) }\end{array}$ \\
\hline Ileum & + & + & + & + & + & + \\
\hline Ischium & + & + & + & + & + & + \\
\hline Pubis & + & + & + & $=$ & + & + \\
\hline Femur & + & + & + & + & + & + \\
\hline Tibia & + & + & + & + & + & + \\
\hline Fibula & + & + & + & - & + & + \\
\hline Tarsus & + & + & + & - & + & + \\
\hline Meta-tarsal & $(5)+$ & (5)+ & $(5)+$ & - & - & - \\
\hline $\begin{array}{l}\text { Phalanges of } \\
\text { toes }\end{array}$ & + & + & + & - & - & - \\
\hline
\end{tabular}

Table 4: Bones of the pelvic girdle and hind-limb of fetuses of the different groups $19^{\text {th }}$ day of gestation.

(+) ossified (-) non-ossified 


\section{Discussion}

Major depression is twice as common in women as in men (Gentile, 2005). Pregnancy and post partum period are considered to be relatively high risk times for a woman with pre-existing psychiatric illnesses, especially for depressive episodes in women (Salvatoer, 2008; Cohen et al, 2010).

Antidepressants alter the working procedure of neuro-transmitters in the body, which pass signals from one brain cell to another thus; they are needed for normal brain function. During depression some of the neurotransmitter systems, particularly those of Serotonin and Noradrenalin, don't work properly. Antidepressants help people with depression by making these natural chemicals more available to the brain (Wan, 2007).

The present study revealed that intraperitonealy injection of pregnant rats with the antidepressant Venlafaxine $(0.25 \mathrm{mg}$. $/ 100 \mathrm{~g}$.body weight ) on day 7 of gestation (the organogenesis period ) induced a very highly significant decrease in the mean maternal body weights these results are in agreement with those of Wessinger et al.( 2006 ) ; Wen et al.(2007) and de Abajo and Rodríguez (2008) who cited that Venlafaxine treatment induced nervousness, loss of appetite, upper gastrointestinal bleeding and body weakness(Li et al.,2011) . Moreover, a very highly significant decrease in the number of live fetuses, fetal body weights and lengths were observed in this study. These results are in agreement with those of Simon $\boldsymbol{e t}$ al. (2002) ., Hendrick et al. (2003) and Mawer et al.( 2010 ). Briggs et al. (2008) cited that treatment of the pregnant mothers with Venlafaxine during the second trimester induced fetal growth retardation. However,the present results showed that lots of congenital anomalies were evident such as subdermal blood bleeding, cleft lips, anomalies of the fore and hind limbs as well as kyphosis of the body.Tthese results are in agreement with those of Källén and Olausson(2007) ; Wogelius et al. (2007)) .,Kimberly and Yonkers(2009) and Wisner et al. (2009) who found increased risk of congenital malformation after exposure to antidepressants in early pregnancy. Briggs et al. (2008) found oral cleft, lung and heart defects and respiratory distress in neonates of mothers of mothers treated with Venlafaxine during pregnancy. Wan (2007) reported that neonatal behavioral signs included central nervous, respiratory, and digestive systems, as well as hypoglycemia and vomiting, tachycardia, and jaundice after exposure to SSRIs and Venlafaxine during pregnancy .

Intraperitonealy injection of pregnant rats with Venlafaxine $(0.75 \mathrm{mg}$. $/ 100 \mathrm{~g}$. b.w. fractionated at 3 doses $0.25 \mathrm{mg} . / 100 \mathrm{~g}$ body weight each) on days 7,10 and 13 of gestation revealed the death of all the pregnant rats.

CoQ10 orally injected to the pregnant rats (0.6mg./100g.body weight) before intraperitonealy injection with Venlafaxine by its two doses resulted in neither maternal death nor fetal death occurred, moreover CoQ10 revealed improvement of the morphometric, morphological, and histological changes, these results are in agreement with those of Haruna et al. (2010)and López et al.,(2010) who cited that the serum CoQ10 levels increase during pregnancy and the levels at the 3rd trimester positively associated with birth weight, they added that the increased CoQ10 during pregnancy may have protective role for fetal growth by its protective role against maternal oxidative stress during pregnancy. Quinzii et al. (2010) found that reactive oxygen species, oxidative stress, and cell death correlate with level of CoQ10 deficiency. Niklowitz et al. (2007) and Maes et al. (2009) cited that depressed patients may benefit from CoQ10 supplementation. The findings that lower CoQ10 is a risk factor to coronary artery disease and chronic heart failure (CHF) and mortality due to $\mathrm{CHF}$, they added that 
CoQ10 supplementation induced platelet level increased, moreover a positive correlation was shown between the plasma CoQ10 level and platelet and white blood cell CoQ10 levels. During CoQ10 supplementation, it may support antioxidative defense mechanisms.

\section{ACKNOWLEGMENT}

The present work was supported by KACST grant no. AT32 -16.

\section{References}

Adan-Manes J, Novalbos J,López-Rodríguez R, Ayuso-Mateos, $\mathbf{J}$ and Abad-Santos $\mathbf{F}$ (2006). Lithium and Venlafaxine interaction: a case of serotonin syndrome. J. Clin. Pharm. Ther., 31 (4): 397-400.

Bancroft J and Gamble and $M$ (2002): Theory and Practice of Histological Techniques $.5^{\text {th }}$ ed., Churchill Livingstone, London.

Bentov $\mathbf{Y}$, Esfandiari $\mathbf{N}$, Burstein $\mathbf{E}$ and Casper R (2010): The use of mitochondrial nutrients to improve the outcome of infertility treatment in older patients. Fertil. Steril., 93(1):272-275.

Briggs G, Freeman $K$ and Yaffe $J$ (2008): Drugs in Pregnancy and Lactation: A reference guide to fetal and neonatal risk. Lippincott, $8^{\text {th }}$ ed.Williams \& Wilkins,pp. 590-592.

Cohen L (2010): Treatment of mood disorders during pregnancy and postpartum. Psychiatric Clinics of North America, 33(2): 273-293.

De Abajo F and Rodríguez L (2008): risk of upper gastrointestinal tract bleeding associated with selective serotonin reuptake inhibitors and Venlafaxine therapy. Arch. Gen. Psychiatr, 65 (7):795-803.

Dimidjian S (2009): Nonpharmacologic intervention and prevention strategies for depression during pregnancy and the postpartum. Clinical Obstetrics and Gynecology ,52(3): 498515.

Gentile S (2005): The safety of newer antidepressants in pregnancy and breastfeeding. Drug Saf., 28: 137-152.

Haruna, M, Matsuzaki M, Tanizaki T, Sekine K, Ota E and Murashima S (2010): Increased serum coenzyme Q10 during pregnancy correlates to birth weight. Biofactors, 36 (4), 312-318.

Hendrick, V., Smith, L., Suri, R., Hwang, S., Haynes, D. and Altshuler L. (2003): Birth outcomes after prenatal exposure to antidepressant medication, 188(3):812-815.

Källén B and Olausson P (2007): Maternal use of selective serotonin re-uptake inhibitors in early pregnancy and infant congenital malformations. Birth Defects Res. Clin. Mol. Teratol., 79:301-308.

Kimberly A and Yonkers M (2009): Parsing risk for the use of selective serotonin reuptake inhibitors in pregnancy. Am. J.Psychiatry, 166:268-270.

Li JJ, Yuan YG, Hou $G$ and Zhang $X$ (2011): Dose-related effects of Venlafaxine on PCREB and brain-derived neurotrophic factor (BDNF) in the hippocampus of the rat by chronic unpredictable stress.

Acta Neuropsychiatrica, 23(1): 20-30.

Littarru G and Tiano, L (2007): Bioenergetic and antioxidant properties of coenzyme Q10: recent developments. Mol. Biotechnol., 37(1):31-37.

López L, Quinzii C, Area E, Naini A, Rahman S, Schuelke M., Salviati L, Dimauro S and Hirano M. (2010): Treatment of CoQ (10) deficient, fibroblasts with Ubiquinone, CoQ analogs, and vitamin C: timeand compound-dependent effects. PLOS One, 5(7): 897-903.

Maes M, Mihaylova I, Kubera M, Uytterhoeven $\mathbf{M}$, Vrydags $\mathbf{N}$ and Bosmans $\mathbf{E}$ (2009): Lower plasma Coenzyme Q10 in depression: a marker for treatment resistance and chronic fatigue in depression and a risk factor to cardiovascular disorders.Neuro Endocrinol. Letters, 30(4):462-469.

Mancuso M., Orsucci D, Volpi L, Calsolaro Vand Siciliano G (2010): Coenzyme Q10 in neuromuscular and neurodegenerative disorders. Current Drug Targets, 11(1):111-121.

Mawer $G$,Briggs $M$ and Baker $G$ (2010): Neurodevelopment group. Pregnancy with epilepsy: obstetric and neonatal outcome of a controlled study. Seizure, 19:112-119.

Niklowitz P, Sonnenschein A, Janetzky B, Andler W and Menke T (2007): Enrichment of coenzyme Q10 in plasma and blood cells: defense against oxidative damage. Int. J. Biol. Sci., 3(4):257-262.

Quinzii C, López L, Gilkerson R, Dorado B,Coku J, http://www.ncbi.nlm.nih.gov/pubmed?term= \%22Naini\%20AB\%22\%5BAuthor\%5D LagierTourenne C Schuelke M., Salviati L , Carrozzo R , Santorelli F, Rahman S ,Tazir $\mathbf{M}$,Koenig $\mathbf{M}$, Di Mauro $\mathbf{S}$ and Hirano $\mathbf{M}$. (2010): Reactive oxygen species, oxidative 
stress, and cell death correlate with level of CoQ10 deficiency. FASEB. J., 24(10):3733-43.

Raudzus A and Misri B (2009): Managing unipolar depression in pregnancy. Mood Disorders Psychiatry, 22(1):13-18.

Rubino A, Roskell N, Tennis P, Mines D and Weich E. (2007): Risk of suicide during treatment with Venlafaxine, Citalopram, fluoxetine, and dothiepin: retrospective cohort study. B.M.J.,334: 242-250.

Salvatore $\mathbf{G}$ (2008): Managing the suicidal risk in pregnant women with severe and persistent psychiatric disorder: Focus on antisuicidal drugs and somatic interventions. Current Psychiatry Reviews, 4(3): 169-184.

Siemieniuk E and Skrzydlewska E (2005): (Coenzyme Q10: its biosynthesis and biological significance in animal organisms and in humans). Postepy. Hig. Med. Dosw., 59:150159.

Simon G,Cunningham M. and Davis R (2002): Outcomes of prenatal antidepressant exposure. Am .J. Psychiatry, 159(12):2055-2061.

Smith C, Hay $\mathbf{P}$ and Mac Pherson $H$ (2010):Acupuncture for Depression. Cochrane Database of Systematic Reviews.20:CD004046.Find this article online.

Taylor P (1986): Handling the reproductive cycle and mating .In: Practical Teratology, Academic Press Inc.London, Copyright C, pp: 39.

Tiihonen J , Lönnqvist J, Wahlbeck K, Klaukka T, Tanskanen Aand Haukka J (2006): Antidepressants and the risk of suicide, attempted suicide, and overall mortality in a nationwide cohort. Arch. Gen. Psychiatry, 63 (12): 1358-1367.
Wan Y (2007): Effects of SSRIs and Venlafaxine during pregnancy in term and preterm neonates. Pediatrics, 119: 52-59.

Wen $\mathbf{S}$, Yang Q, Fraser $\mathbf{W}$, Olatunbotsun O Nimord G and Walker X (2007): Selective serotonin reuptake inhibitors and adverse pregnancy outcomes. Am.J.Obstet.Gynecol., 196(4): 961-966.

Wessinger S, Kaplan M, Choi L, Williams M, Lau C, Sharp L, Crowell M, Keshavarzian A and Jones M(2006): Increased use of selective serotonin reuptake inhibitors in patients admitted with acute gastrointestinal hemorrhage: a multicentre retrospective analysis. Aliment. Pharmacol. Ther., 23(7):937-944.

Wisner K, Sit D, Hanusa B, Moses-Kolko E,Bogen D and Hunker D (2009): Major depression and antidepressant treatment: Impact on pregnancy and neonatal outcomes. Am. J.

Psychiatry, 164:1206-1213.

Wogelius P, Norgaard M, Gislum M, Pedersen L, Munk E, Mortensen P, Lipworth L and Sorensen H (2007): Maternal use of selective serotonin reuptake inhibitors .Epidemiology, 18(3):411-412.

Yonkers K (2009): The management of depression during pregnancy: A Report from the American Psychiatric Association and the American College of Obstetricians and Gynecologists, General Hospital Psychiatry ,31(5): 403-413. 

The role of.....

\section{دور الإنزيم المساعد كيو 10 فى تعديل التغيرات التى يحثنها مضاد الاكتاب فينلافاكسين فى أجنة الجرذان البيضاء البئ}

$$
\text { هناء أبوجبل*، فوزية الشبانات** }
$$

$$
\begin{aligned}
& \text { * *لية العلوم و الدر اسات الإنسانية ،جامعة سلمان بن عبد العزيز }
\end{aligned}
$$

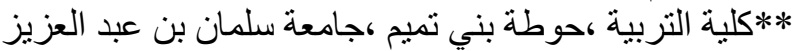

يهدف هذا البحث إلى در اسة دور الإنزيم المساعد كيو 10 في الحد من التغير ات في الثكل الظاهري كذلك التهاء

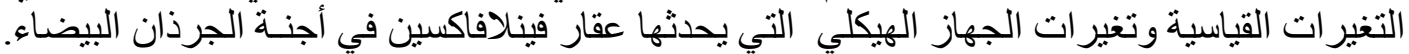

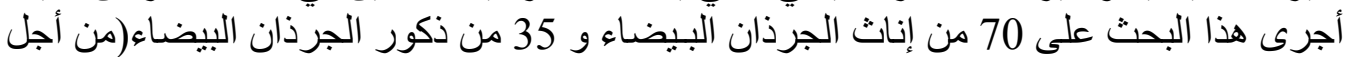

\section{كما تم تقسيم حيوانات التجارب إلى ثلاث مجموعات رئيسية:}

1-المجموعة الضابطة (المجموعة الطبيعية):

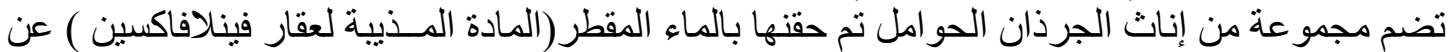

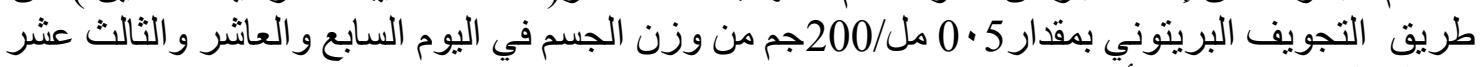
من الحمل(فترة تكوين الأعضاء).

2- المجموعات الضابطة التجريبية:

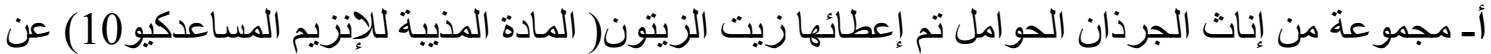

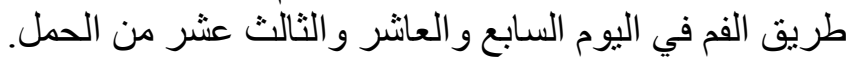
بـ مجمو عة من إناث الجرذان الحو امل تم إعطائها الإنزيم المساعد كيو 10 عن طريق الفم بجر عة مقدار ها

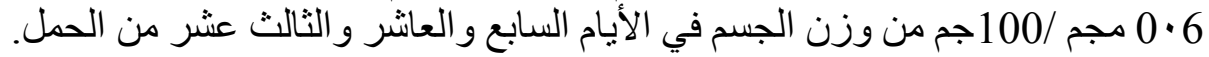

3-المجموعات التجريبية:

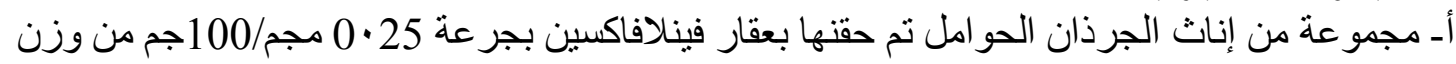
الجسم عن طريق التجويف البرينوني في اليوم السابع من التئ الحمل.

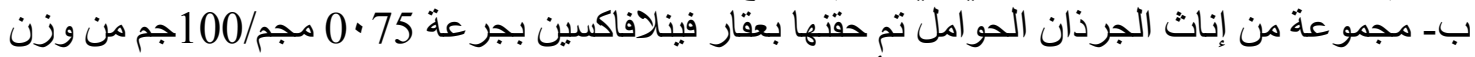

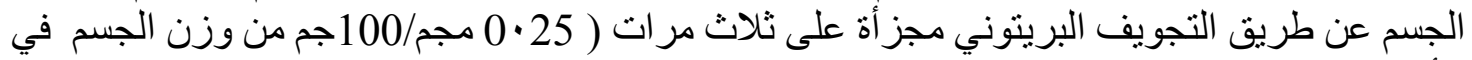
الأيام السابع و العاثر و الثالث عثر من الحمل).

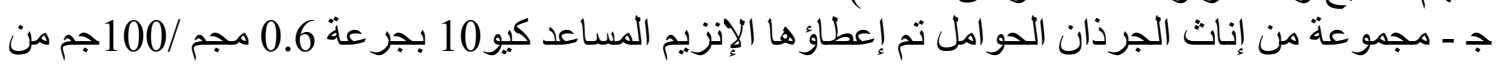

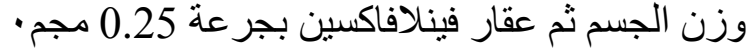

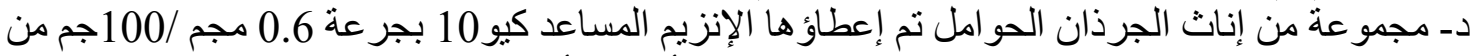

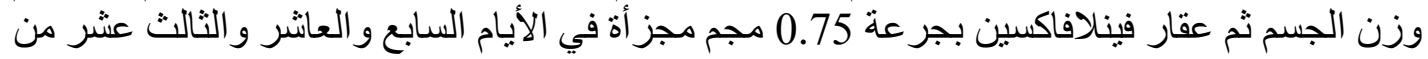

نتائج الاراسات التي أجريت على الجرذان الحوامل:

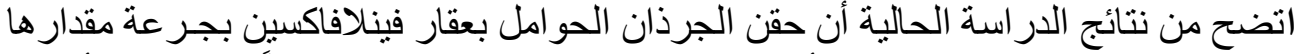

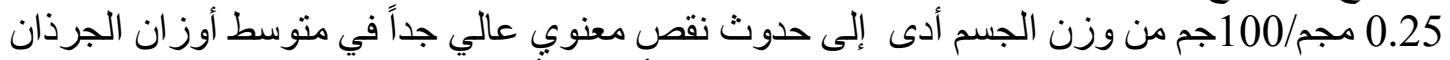
الحو امل و عدم تساوي قرني الرحم في الطول حيث ظهر أحدهما أقصر من الآخر بالإضافة على لعدم تساوي 


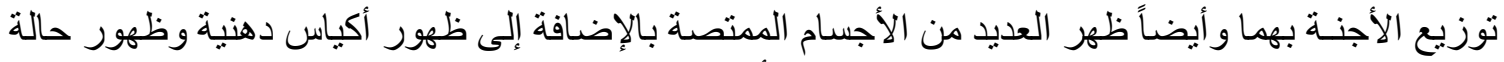

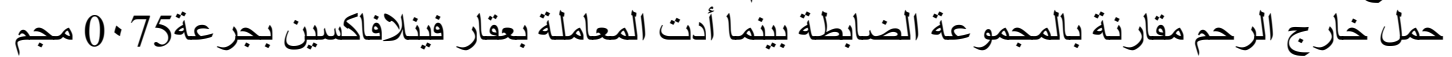

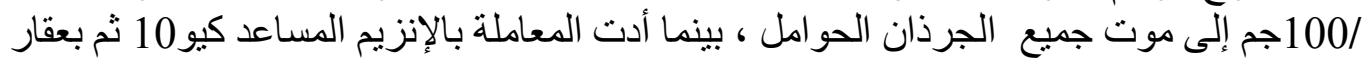

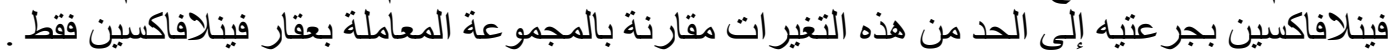

\section{نتائج الدراسات التي أجريت على الأجنة:}

الار اسات القياسية:

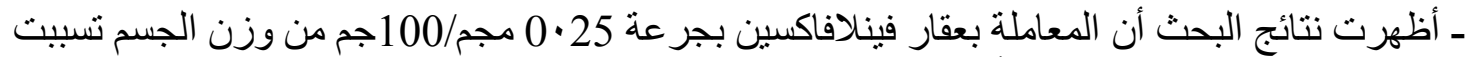

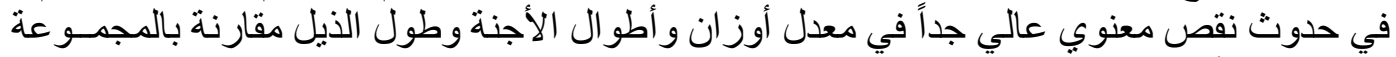

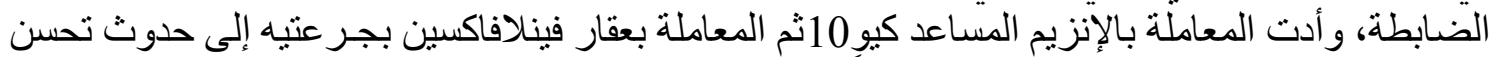

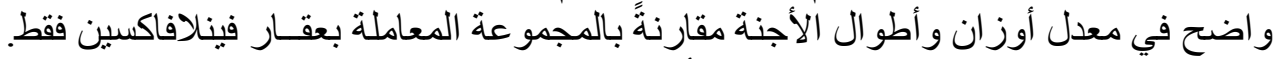

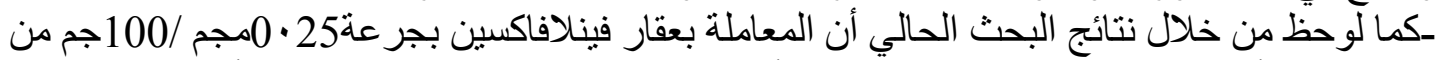

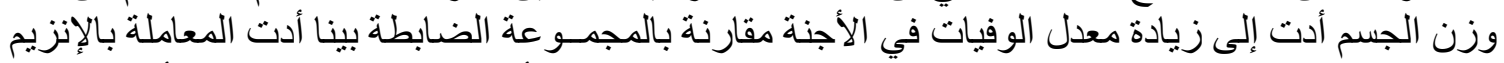

المساعد كيو 10ثم بعقار فينلافاكسين بجر عتيه إلى تحسن معدل عدد الأجنة الحية حيث لم تسجل أب حالة الته

الار اسات الظاهرية:

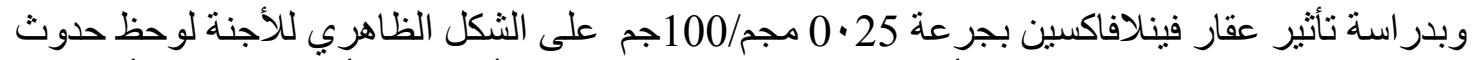

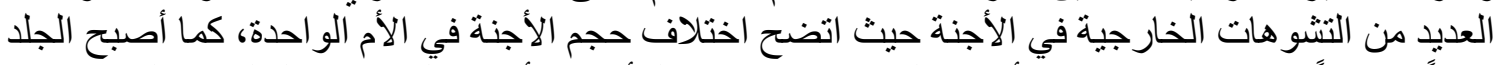

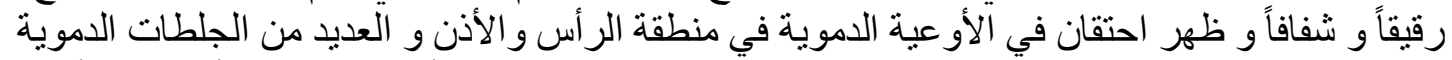

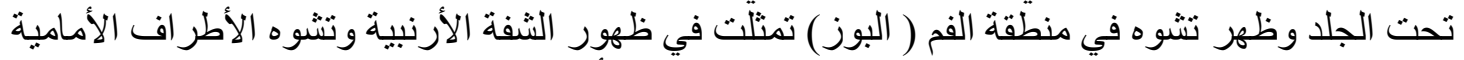
والخلفية وتضخم في منطقة البطن وتقوس الظهر بينما لوحظ أن المعاملة بالإنزيم المساعد كيو 10 ثم ثمعقار فينالافاكسين بجر عتيه أدت إلى الحد من التشوهات التي سببها عقار فينلافاكسين.

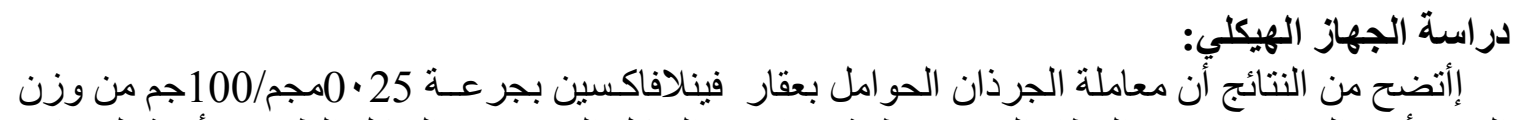

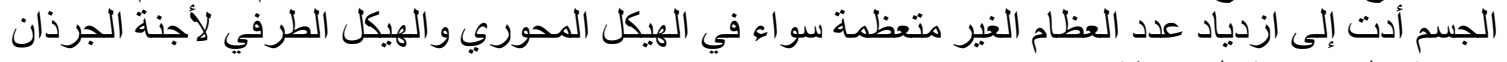

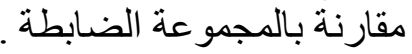
بينما أدت المعاملة بالإنزيم المساعد كيو 10 ثم بعقار فينالافاكسين بجر عتيه إلى تحسن ملحوظ في تعظم الجهاز الهيكلي مقارنة بالمجمو عة المعاملة بعقار فينالافاكسين فقط. 